\title{
Z dziejów sądów przysięgłych na ziemiach polskich w XIX wieku
}

Instytucja sądu przysięgłych nie ma ani długiej, ani bogatej tradycji w polskim systemie wymiaru sprawiedliwości. Powołana do życia dopiero w połowie XIX w. przez ustawodawców zaborczych, a następnie - po odzyskaniu przez Polskę niepodległości - utrzymana w ograniczonym zakresie przez polskiego ustawodawcę, funkcjonowała zaledwie przez kilka dekad. Znacznie dłużej zaznaczała się jednak w sferze poglądów i projektów formułowanych głównie przez środowiska prawnicze. Najstarszy projekt powołania jej na ziemiach polskich pochodzi z czasów Księstwa Warszawskiego (z 1811 r.), kolejny z okresu konstytucyjnego Królestwa Polskiego (z 1819 r.) i choć zabrakło wówczas akceptacji ustawodawcy oraz odpowiednich warunków do ich zrealizowania, wywołały pierwszą na terenie ziem polskich debatę o sądach przysięgłych.

Pod rządami zaborców sądy te pojawiły się niemal równocześnie w zaborze pruskim (w 1849 r.) i austriackim (w 1850 r.), a nieco później - w 1864 r. - w tej części zaboru rosyjskiego, która nie tworzyła Królestwa Polskiego, czyli na tzw. Ziemiach Wschodnich. W okresie II Rzeczypospolitej sądy przysięgłych istniały, ale tylko na obszarze dawnego zaboru austriackiego. Idea sądownictwa przysięgłych pozostawała żywa także w powojennej Polsce, gdy na krótko w latach czterdziestych narodziła się koncepcja ich przywrócenia.

Sądy przysięgłych były instytucją, która przez cały czas budziła żywe emocje, wywoływała spory i dyskusje, dzieliła prawników, a nawet powodowała polaryzowanie się ich poglądów. Oczywiście, jedne argumenty przemawiały za jej wprowadzeniem w wieku XIX, inne - za utrzymaniem w niepodległej Polsce, jeszcze kolejne stały się inspiracją dla ich powojennych zwolenników. W różnych epokach, a zwłaszcza warunkach prawno-politycznych, zmieniała się też motywacja jej przeciwników.

Warto, jak sądzę, przypomnieć zarówno tę polemikę, jak i stosowane w praktyce rozwiązania ustrojowe i proceduralne. Niniejszy artykuł dotyczy pierwszego, naturalnie wyodrębniającego się okresu, lat zaborów. Aspiracje polskie musiały wówczas zetrzeć się z reakcją zaborców, a przede wszystkim 
uwzględniać polityczne uwarunkowania. To zaborcy decydowali ostatecznie o formie prawno-ustrojowej ziem polskich, ciekawe są więc ich poglądy na istotę i kształt tej instytucji. Poglądy krystalizujące się w środowisku polskich prawników na temat sądów przysięgłych nie miały wówczas bezpośredniego wpływu na rozwój prawodawstwa karnego zaborców ani na ewentualne zmiany w ustroju sądownictwa, ale stanowiły wyraz zainteresowania rozwojem różnych instytucji prawnych, a także bazę dla prac ustawodawczych w niepodległej już Polsce. Część druga, poświęcona okresowi międzywojennemu, znajduje się już w opracowaniu.

Sama instytucja doczekała się zainteresowania badaczy i częściowych przynajmniej opracowań. Na łamach „Czasopisma Prawno-Historycznego” ukazał się w roku 1989 artykuł Piotra Stachańczyka poświęcony jej funkcjonowaniu $\mathrm{w}$ pierwszej dekadzie dwudziestolecia międzywojennego ${ }^{1}$. O najdawniejszych projektach sądów przysięgłych, również na łamach „Czasopisma Prawno-Historycznego", pisał natomiast w latach pięćdziesiątych Wiesław Daszkiewicz².

I. Tradycja europejska. Najdawniejsza europejska tradycja związana z sądami przysięgłych dotyczy - jak wiadomo - angielskiego systemu wymiaru sprawiedliwości. Ich początki sięgają tam nawet XIII w., choć ostatecznie skrystalizowały się w wieku XVI ${ }^{3}$. Sądy przysięgłych w Anglii rozwijały się w dwóch formach: wielkiej ławy (grand jury), orzekającej o wprowadzeniu obwinionego w stan oskarżenia, oraz małej ławy (petty jury), wydającej orzeczenie o winie, o ile oskarżony w trakcie rozprawy nie przyznał się sam do winy. Obydwie formy rozwijały się stopniowo, ewolucyjnie, na przestrzeni wieków, stając się naturalnym elementem angielskiego wymiaru sprawiedliwości, nieutożsamianym z jakimś konkretnym kierunkiem aktualnie prowadzonej polityki.

$\mathrm{Na}$ kontynencie instytucja ta pojawiła się znacznie później - w sądownictwie czynnik społeczny istniał tu wprawdzie od dawna, ale przybierał inne formy - a rozwijała w zupełnie innym klimacie, nasączonym określonymi politycznymi ideami i celami. Była wykorzystywana do ich osiągnięcia i likwidowana lub czasowo zawieszana, gdy doraźne cele się zmieniały. Została w pewnym sensie upolityczniona. Przyniosła ją francuska rewolucja wraz z hasłami wolności, równości i braterstwa, rozwijanymi w sferze władzy są-

${ }^{1}$ P. Stachańczyk, Są przysięgtych $w$ ustawodawstwie karnym i doktrynie $w$ Polsce $w$ latach 1918-1929, „Czasopismo Prawno-Historyczne” 1989, T. XLI, z. 1, s. 109-134.

${ }^{2}$ W. Daszkiewicz, Projekt procedury dla przysieglych z 1819 r., „Czasopismo Prawno-Historyczne” 1958, T. X, z. 1, s. 125-152 i Próby reform procesu karnego w Królestwie Polskim, „Czasopismo Prawno-Historyczne" 1956, T. VIII, z. 1, s.209-257.

${ }^{3}$ Zob. S. Płaza, Historia prawa w Polsce na tle porównawczym, cz. I: X-XVIII w., Kraków 2002, s. 528-529 i 600-601. 
downiczej pod postacią udziału w niej społeczeństwa, właśnie w formie sądów przysięgłych. Wprowadzono je we Francji dzięki ustawodawstwu z lat 1790-1791, wzorując się na, jedynym wówczas, angielskim modelu organizacyjnym. Dlatego też pierwotnie sądy przysięgłych we Francji miały postać obydwu ław przysięgłych: jury d'accusation, która decydowała o skierowaniu sprawy do sądu, i jury du jugement, orzekającej o winie i stanowiącej wraz $\mathrm{z}$ trybunałem zawodowym, orzekającym o skutkach prawnych werdyktu przysięgłych, sąd właściwy. Ława przysięgłych orzekająca o winie składała się z 12 osób i głosowała większością 10 głosów (choć początkowo projektowano jednomyślność). Sądy przysięgłych powołane do życia we Francji okresu rewolucji, przetrwały kolejne zmiany ustrojowe, choć uległy pewnym modyfikacjom. Ustawa postępowania karnego z 1808 r. (Code d'instruction criminelle), a więc z czasów napoleońskich, zniosła bowiem ostatecznie wielką ławę ${ }^{4}$. Z czasem pojawiły się też głosy krytyczne odnośnie do instytucji sądów przysięgłych. Francuski filozof i kryminolog Gabriel Tarde dowodził nawet, że jej utrzymanie oznacza dla wymiaru sprawiedliwości zastój i brak skuteczności. Podkreślał, że instytucja dostosowana do systemu angielskiego i tam sprawdzająca się w praktyce, zupełnie nie przystaje do warunków francuskich ${ }^{5}$.

Sąd przysięgłych w czasach wprowadzania go na kontynencie europejskim, a więc w XIX w., definiowano jako

„takie urządzenie sądowe, w którym obywatele nie znający specjalnie prawa, do każdej pojedynczej sprawy oddzielnie wylosowani, a mogący być przez strony wyłączani, orzekają na mocy przedstawionych im dowodów o winie lub niewinności podsądnego, w ten sposób, iż ich orzeczenie służy za podstawę wyroku mającego się wydać przez sąd państwowy"6.

Przysięgli nie działali samoistnie, lecz łącznie i pod przewodnictwem sądu państwowego, który w Anglii był reprezentowany przez jednego sędziego, a na kontynencie przez kolegium sędziów, wyznaczanych do każdej sesji sądu przysięgłych. Przysięgli rekrutowali się spośród członków społeczeństwa $\mathrm{w}$ ścisłym trybie, określonym przepisami prawa, różniącymi się w poszczególnych państwach pod względem koniecznych do spełnienia warunków (dotyczących wieku, wykształcenia, stopnia zamożności itp.). Na ogół wymogi te wskazywały, że przysięgłymi mogli być mężczyźni, posiadający pełnię praw cywilnych i politycznych, zdrowi na ciele i umyśle, mający pewien minimalny dochód lub majątek, potrafiący pisać i czytać. Ponieważ za

${ }^{4}$ W. Makowski, Podstawy filozofii prawa karnego, T. 1, cz. 1-2, Warszawa 1917, s. 366.

5 P. Stebelski, Sady przysięglych i sądy tawnicze, [w:] Księga pamiatkowa ku uczczeniu 250-tej rocznicy zatożenia Uniwersytetu Lwowskiego przez króla Jana Kazimierza w 1661, T. 2, Lwów 1912, s. 9.

${ }^{6}$ W. Miklaszewski, O znaczeniu sądów przysięgłych, Warszawa 1867, s. 4. 
jedną z najważniejszych rękojmi sprawiedliwego wymiaru sprawiedliwości uznawano bezstronność wyrokujących, w tym sędziów przysięgłych, dopuszczano możliwość wyłączania poszczególnych przysięgłych przez oskarżonego. Prawodawstwo angielskie uwzględniało tę zasadę najpełniej, pozwalając oskarżonemu na wyłączenie znacznej liczby przysięgłych i to bez podania powodów. Sąd przysięgłych wyrokował w Anglii we wszystkich sprawach karnych z wyłączeniem spraw najdrobniejszych, podlegających jurysdykcji sądów pokoju. Na kontynencie właściwość rzeczowa została określona znacznie szczuplej i sądom przysięgłych przekazano tylko sprawy największej wagi: najczęściej zbrodnie zagrożone najwyższym wymiarem kary, czasem również - choć nie zawsze - przestępstwa polityczne i/lub przestępstwa prasowe. Całkowita zgodność prawodawstwa na kontynencie dotyczyła zupełnej rezygnacji z udziału przysięgłych w postępowaniu cywilnym oraz w postępowaniu karnym w najlżejszych występkach i wykroczeniach. Nie przyjęła się też ostatecznie na kontynencie ława przysięgłych decydująca o postawieniu w stan oskarżenia. Obecna w systemie angielskim (grand jury), na moment przyjęta przez ustawodawstwo francuskie (jury d'accusation), nie znalazła tu sprzyjających warunków rozwoju.

Oprócz odmienności występujących pomiędzy modelem angielskim i kontynentalnym $\mathrm{w}$ zakresie właściwości sądów przysięgłych, istotne różnice dotyczyły też postępowania sądowego z udziałem przysięgłych. W Anglii przyznanie się do winy oskarżonego tradycyjnie uznawano za wystarczający dowód, zastępujący orzeczenie przysięgłych i wyłączający całe postępowanie $\mathrm{z}$ ich udziałem. Zadaniem sędziego zawodowego było w takim wypadku jedynie wymierzenie kary. Na kontynencie przyznanie się oskarżonego do winy traktowano jako jeden z dowodów, podlegających ocenie przysięgłych, a więc niewyłączający ich udziału w postępowaniu. Takie rozwiązanie bardziej odpowiadało tym systemom wymiaru sprawiedliwości, w których sądownictwo przysięgłych nie rozwijało się ewolucyjnie, lecz zostało wprowadzone wolą ustawodawcy. W przebiegu rozprawy uwypuklały się kolejne różnice. W Anglii rozprawa zmierzała z jednej strony (oskarżycielskiej) do ustanowienia dowodu winy, czyli udowodnienia aktu oskarżenia, z drugiej (obrończej) do jego obalenia lub choćby wykazania jego niedostatków. Rolą przewodniczącego sądu było na koniec streszczenie przysięgłym przedstawionych na rozprawie dowodów, zaznaczenie pojawiających się wątpliwości oraz wyjaśnienie zasad oceniania dowodu przez naukę i praktykę. W procedurach kontynentalnych rozprawa kierowana przez przewodniczącego zmierzała przede wszystkim do wydobycia z oskarżonego przyznania się do winy, a przynajmniej do wszechstronnego wyjaśnienia sprawy jego odpowiedziami; dalsze dowody w postępowaniu były dopuszczane przez przewodniczącego według jego uznania i w porządku przez niego uznanym za właściwy, on sam przesłuchiwał świadków i biegłych, dopuszczając oskarżyciela oraz oskarżonego i obrońcę do zadawa- 
nia pytań. Na koniec miał obowiązek przedstawienia przysięgłym raz jeszcze wszystkich dowodów przedstawionych w postępowaniu, unikając wyrażania własnego zdania co do winy oskarżonego. Inny był też charakter przemówień prokuratora i obrońcy, co miało ścisły związek z różnymi zasadami oceniania winy oskarżonego. Przysięgli angielscy orzekali o winie lub niewinności, kierując się, sformułowanymi przez naukę i praktykę sądową, zasadami oceniania przedstawionych dowodów. Przysięgli na kontynencie mieli się natomiast kierować wewnętrznym przekonaniem, wrodzonym każdemu człowiekowi poczuciem sprawiedliwości, które nakazywało w danej sprawie stwierdzić winę oskarżonego lub jej brak. Obrońca angielski starał się więc w swojej końcowej mowie prawnie dowieść, czy dany dowód istniał czy nie, obrońcy na kontynencie musieli starać się wpłynąć na uczucia, emocje i wrażliwość przysięgłych. Różnice uwidaczniały się także w przebiegu narady przysięgłych. W Anglii przysięgli mieli stwierdzić jedynie winę lub jej brak, na kontynencie - mieli odpowiedzieć na zadane im przez przewodniczącego pytania, które osobno dotyczyły różnych warunków wpływających na ocenę przestępstwa. W Anglii przysięgli orzekali o winie jednomyślnie, na kontynencie na ogół większością, choć różnie określaną (od 7 do 10 głosów na 12).

II. Pierwsze polskie projekty sądów przysięglych. Pierwsze próby wprowadzenia instytucji przysięgłych na ziemiach polskich były związane z istnieniem Księstwa Warszawskiego. Za sprawą ministra sprawiedliwości Feliksa Łubieńskiego w 1810 r. rozpoczęto przygotowania do wprowadzenia francuskiego kodeksu postępowania karnego z 1808 r., który uwzględniał istnienie tej instytucji. Projekt procedury dla Księstwa, w stosunku do francuskiego oryginału trochę zmieniony z uwagi na różnice wynikające z ustawodawstwa obowiązującego na terenie Księstwa, został przygotowany w Sekcji Sprawiedliwości Rady Stanu, a następnie przedstawiony samej Radzie Stanu w dniu 23 stycznia 1811 r. przez referendarza Michała Woźnickiego. Dyskusje w Radzie Stanu nad projektem toczyły się w dniach 23 stycznia i 30 marca 1811 r. i w dużej mierze dotyczyły właśnie sądów przysięgłych.

Projekt przewidywał, zgodnie z francuskim wzorem, podział przestępstw na: przewinienia, występki i zbrodnie (zagrożone więzieniem powyżej 5 lat). Te ostatnie miały być rozpoznawane właśnie przez sądy przysięgłych (co ciekawe, wyłączono spod ich jurysdykcji przestępstwo kradzieży). Sąd przysięgłych dla danego departamentu miał się zbierać na sesje co 3 miesiące i składać z sędziów zawodowych delegowanych z sądu cesarskiego (cour imperiale) lub z trybunału cywilnego pierwszej instancji oraz z przysięgłych (jury). Sąd przysięgłych nosił w projekcie nazwę Cour d'assise, co tłumaczono jako sąd delegacyjny. Wyroki sądu przysięgłych były wzruszalne wyłącznie w drodze kasacji kierowanej do Sądu Kasacyjnego. Przysięgli mieli być wybierani spośród ludności departamentu w taki sposób, że najpierw miano wyłaniać do 
każdej sprawy grupę 36 osób i dopiero z niej 12-osobową ławę. W doborze przysięgłych decydującą rolę miały odgrywać władze prefekturalne, a warunki jakie musieli spełniać kandydaci, były możliwe do spełnienia przez dość wąską grupę (opłacanie wysokich podatków, posiadanie dużego majątku, pobieranie wysokiej pensji, pełnienie urzędu administracyjnego, wykształcenie akademickie). Ława przysięgłych miała orzekać o winie, sędziowie zawodowi o karze. Przysięgli mieli głosować nad orzeczeniem o winie zgodnie z zasadą większości głosów, a w razie równości głosów decydować miało stanowisko korzystniejsze dla oskarżonego. Wobec uznania oskarżonego za niewinnego sąd miał obowiązek natychmiast uwolnić oskarżonego, zaś w razie stwierdzenia winy - orzec karę ${ }^{7}$.

Sekcja Sprawiedliwości Rady Stanu upatrywała w instytucji przysięgłych wiele pożytków i dlatego optowała za jej wprowadzeniem, pomimo braku wcześniejszych doświadczeń na ziemiach polskich z nimi związanych oraz krótkiej ciągle jeszcze, a więc nie do końca zweryfikowanej, ich tradycji w ustawodawstwie francuskim.

„Pierwszy [pożytek - M. M.P.], iż los obwinionego nie zostanie tylko w ręku uczonego sędziego, którego serce przez ciągłe wykonywanie obowiązków w sądownictwie kryminalnym, mniej czułym na ułomność ludzką stać się może. Drugi, że przypuszczenie obywateli do wyrokowania w najdelikatniejszej materii wzbudza w nich zaufanie do rządu i uczy ich cenić swą własną godność. Trzeci najistotniejszy użytek, iż deklaracja przysięgłych uznając obwinionego winnym lub niewinnym, znosi ten środkowy punkt, który dotąd w sądownictwie kryminalnym zostawiał plamę na obwinionym, gdy ten w braku zupełnego dowodu, nie mogąc być i wskazanym na karę zwyczajną zadanej mu zbrodni, dla samych jednak porozumień (iudicia), jeżeli te były bardzo mocne nie wychodził zupełnie bez kary i pozbawiony był sławy"8.

Sekcja Sprawiedliwości wskazała jednak równocześnie te zarzuty, które podnoszono już we Francji przeciwko sądom przysięgłych, a potem w Księstwie, po zapoznaniu się z francuską procedurą karną, były podtrzymywane. Do najważniejszych zaliczano brak odpowiedniego prawniczego wykształcenia przysięgłych i w związku z tym ich niefachowość, niepotrzebne koszty dla obywateli związane z uczestnictwem w posiedzeniach sądu, problemy proceduralne pojawiające się w razie niestawienia się odpowiedniej liczby przysięgłych i wreszcie - możliwość oddziaływania zewnętrznego na przysięgłych, a co za tym idzie - możliwy brak obiektywizmu przy wyrokowaniu?

${ }^{7}$ AGAD, Akta Rady Stanu i Rady Ministrów Księstwa Warszawskiego, protokoły, sygn. 90, s. $14-15$.

${ }^{8}$ Ibidem, s. 16.

${ }^{9}$ Ibidem, s. 16-17. 
Największym przeciwnikiem sądu przysięgłych w obradującym gronie okazał się radca stanu, członek Sekcji Sprawiedliwości Franciszek Grabowski. Stwierdził on, że instytucja ta, choć we Francji była możliwa do przyjęcia, to w Księstwie z uwagi na inne uwarunkowania polityczno-społeczne powinna zostać odrzucona. Podnosił przede wszystkim kwestię braku odpowiedniej liczby przygotowanych i gotowych do jej pełnienia osób. Za niezgodny z konstytucją i niezrozumiały uznawał brak apelacji od wyroków sądów przysięgłych ${ }^{10}$. Stanowisko Grabowskiego było jednak w Radzie Stanu odosobnione. W obronie sądów przysięgłych wystąpił m.in. radca stanu Stanisław Staszic, a minister Feliks Łubieński podkreślał wręcz:

„taka instytucja stałaby się mocną sprężyną do upowszechnienia cywilizacji w dalszych pokoleniach. Poprawia moralność przez większe wrażenia, kiedy sama społeczność członka swego sądzi i sama przekonawszy się o jego zbrodni wydaje wyrok, a sędzia aplikuje prawo" 11 .

Prace nad projektem w Radzie Stanu przedłużały się i nie został on ostatecznie przygotowany przed rozpoczęciem obrad sejmu w 1811 r. Później zaś wydarzenia polityczne rozegrały się szybko i po klęsce Napoleona kwestia wprowadzenia nowej procedury karnej, a tym samym instytucji przysięgłych, została zawieszona do nieoznaczonego bliżej momentu ${ }^{12}$.

Sprawa sądu przysięgłych odżyła jednak stosunkowo szybko, bo już w pierwszych latach po kongresie wiedeńskim, tym razem na obszarze utworzonego Królestwa Polskiego. Była częścią szerszego zamysłu zreformowania procedury karnej, ciągle tej samej prusko-austriackiej, którą minister Łubieński chciał już wcześniej zastąpić prawem francuskim. W pracach nad nową procedurą karną od początku uwzględniano instytucję sądu przysięgłych, biorąc pod uwagę projekty i argumenty dyskutowane jeszcze w czasach Księstwa Warszawskiego. Podczas posiedzeń Rady Stanu Królestwa Polskiego, w grudniu 1817 r., w obronie sądów przysięgłych wypowiedziało się wielu jej członków, m.in. Stanisław Staszic, Adam Czartoryski, Ludwik Plater, Kalasanty Szaniawski oraz minister spraw wewnętrznych i policji Tadeusz Mostowski. Nie brakowało jednak też głosów krytycznych, czy choćby nakazujących ostrożność we wprowadzaniu niesprawdzonych rozwiązań. W tym duchu wypowiedzieli się Ksawery Potocki i Ignacy Sobolewski. Ostatecznie jednak Rada Stanu podjęła uchwałę zalecającą wprowadzenie instytucji i powołała w związku z tym specjalny komitet. W dniu 19 grudnia 1817 r. komitet ten przedstawił Radzie Stanu opracowane zasady organizacji sądów przysięgłych, nad którymi odbyła się dyskusja i które zostały ostatecznie przyję-

\footnotetext{
${ }^{10}$ Ibidem, s. 128-132.

${ }^{11}$ Ibidem, s. 22.

${ }^{12}$ W. Daszkiewicz, Próby reform procesu karnego..., s. 212-213.
} 
te. W myśl tych zasad sądy przysięgłych miały działać przy każdym sądzie grodzkim i orzekać - przynajmniej początkowo - tylko w sprawach najcięższych przestępstw (zbrodni). Ława przysięgłych została zredukowana do 8 osób. Warunki konieczne do pełnienia funkcji przysięgłego to: ukończone 30 lat, posiadanie prawa do głosowania na sejmikach i zgromadzeniach gminnych i umiejętność pisania i czytania. Dopuszczono możliwość uznania przez sąd grodzki istotnej pomyłki w orzeczeniu ławy przysięgłych, co skutkowało możliwością powołania następnego składu przysięgłych. Dopuszczano też, tak jak w projekcie z czasów Księstwa Warszawskiego, kasację do Trybunału Najwyższego ${ }^{13}$. W oparciu o przyjęte przez Radę Stanu zasady został opracowany „Projekt procedury dla przysięgłych”, którego najbardziej prawdopodobnym autorem był sędzia Ksawery Potocki ${ }^{14}$. Odbiegał on znacznie od projektu z czasów Księstwa Warszawskiego. Przede wszystkim za wzór przyjął angielski, a nie francuski model sądownictwa przysięgłych. Oznaczało to przede wszystkim powołanie dwóch, a nie jednej ławy przysięgłych: większej, decydującej o oddaniu pod sąd, i mniejszej, orzekającej o winie oskarżonego. Inny był też system środków odwoławczych. O ile projekt z czasów Księstwa przewidywał tylko kasację od wyroku sądu przysięgłych, tutaj dopuszczono również apelację. Zasadniczo różnił się też skład i sposób powoływania przysięgłych. Przede wszystkim w doborze osób wpisanych na listy przysięgłych nie miał, tak jak w projekcie z czasów Księstwa, decydującego wpływu czynnik administracyjny, lecz losowanie. Warunki natomiast jakie miał spełniać kandydat do funkcji przysięgłego były mniej ekskluzywne: ukończone 30 lat i „majątek lub sposób do życia wystarczający bądź z własnej dziedzicznej, bądź z posesji czy uczonego, czy handlowego czy rzemieślniczego stanu pochodzący" ${ }^{15}$. Wspólną natomiast cechą obydwu projektów było wąskie określenie właściwości rzeczowej sądów przysięgłych, ograniczającej się do najcięższych przestępstw - zbrodni, z wyłączeniem przestępstwa kradzieży.

Projekt został rozesłany do zaopiniowania przedstawicielom środowiska prawniczego, którzy w większości wypowiedzieli się negatywnie. W dniu 14 sierpnia 1819 r. namiestnik Józef Zajączek oznajmił, że instytucję tę należy w związku z tym odrzucić i polecił Ksaweremu Potockiemu opracowanie projektu procedury karnej nieuwzględniającej już jej istnienia. Ostatecznie Rada Stanu na posiedzeniu w dniu 24 września 1819 r. w formalnym głosowaniu wypowiedziała się większością 12 głosów przeciwko 10 za odrzuceniem instytucji ${ }^{16}$.

Projekt procedury karnej opracowany przez Ksawerego Potockiego został wniesiony pod obrady sejmu obradującego w 1820 r., a debata nad nim roz-

${ }^{13}$ W Daszkiewicz, Projekt procedury dla przysięgłych..., s. 130-133.

${ }^{14}$ Zob. uwagi odnośnie do autorstwa projektu: ibidem, s. 133-134.

${ }^{15}$ Zob. tekst projektu: ibidem, s. 139.

${ }^{16}$ Ibidem, s. 138. 
poczęła się w dniu 22 września. Co ciekawe, największą burzę wywołał brak w nim instytucji przysięgłych. Wielu posłów i deputowanych, m.in. Dominik Krysiński, Leon Dembowski, Bonawentura Niemojowski, Wincenty Niemojowski czy Michał Potocki, domagało się jej wprowadzenia. Twierdzono, że sądy te są „prawdziwą rękojmią niepodległości” i „podstawowymi filarami sądownictwa”. Wywodzono, że konieczność ich powołania wypływa wprost z zasady umowy społecznej. Podkreślano, że tylko przysięgły „, z tą bezstronnością i uwagą sądzi współobywatela, z jaką sam chciałby być sądzonym"17. Projekt procedury karnej ostatecznie przez sejm został odrzucony przytłaczającą większością: za projektem opowiedziało się tylko 3 posłów, 117 było przeciw.

Idea zorganizowania sądów przysięgłych doczekała się w Królestwie Polskim realizacji nieco później, w niecodziennych, choć przejściowych okolicznościach. Wprowadził je bowiem kodeks karny Gwardii Narodowej Warszawskiej w czasie powstania listopadowego. Ich zasięg, zarówno czasowy (nie mogły przetrwać dłużej), jak i personalny (ograniczony do członków Warszawskiej Gwardii Narodowej) był niewielki, ale stanowią ciekawy pomnik polskiego prawodawstwa karnego. Sądy przysięgłych przybrały postać tzw. sądów karności, które były tworzone w każdym pułku gwardii, a ich właściwość obejmowała wyłącznie wykroczenia. Składały się z 3 sędziów, wyznaczanych przez dowódcę pułku spośród oficerów Gwardii oraz 6 przysięgłych ( 2 oficerów, 2 sierżantów i 2 żołnierzy Gwardii) powoływanych w drodze losowania ${ }^{18}$. Od wyroków tych sądów przysługiwał specjalny środek zaskarżenia, tzw. opozycja, rozpatrywana przez ten sam skład; mogła ona jednak dotyczyć tylko kary. Oprócz pułkowych sądów karności funkcjonował też Sąd Wojenny dla Gwardii, składający się z 5-osobowego trybunału i 12-osobowej ławy przysięgłych. Był on właściwy dla cięższych przestępstw popełnionych w trakcie służby, lecz nie w polu walki. Od wyroku Sądu Wojennego przysługiwała kasacja, którą rozpatrywał Sąd Wojenny Kasacyjny Gwardii, któremu przewodniczył naczelnik Gwardii ${ }^{19}$.

Na obszarze Królestwa Polskiego raz jeszcze, na początku lat 60. XIX w., sprawa zorganizowania sądownictwa przysięgłych stała się aktualna. W marcu 1862 r. Minister Sekretarz Stanu Królestwa Polskiego, korzystając ze sprzyjającego klimatu politycznego, obwieścił zamiar przystąpienia do opracowywania nowych projektów ustawodawczych w zakresie procedury karnej oraz ustroju sądownictwa. W zakresie organizacji sądów projekt przygotował ostatecznie Małkowski, a projekt procedury karnej - Władysław Holewiński. Zakładały one powołanie sądów przysięgłych. Projekt procedury karnej był

${ }^{17}$ Dziennik posiedzeń Izby Poselskiej w czasie Sejmu Królestwa Polskiego w roku 1820 odbytego, s. 28 i nast. Podaję za: W. Daszkiewicz, Próby reform procesu karnego..., s. 231.

${ }^{18}$ Ibidem, s. 233-241.

${ }^{19}$ M. Stanulewicz, Sąy i prawo w powstaniu styczniowym, Poznań 2005, s. 40-41. 
znowu wzorowany na procedurze francuskiej z $1808 \mathrm{r}$. Przewidywał istnienie tzw. sądu zbrodniowego składającego się z 3 sędziów sądu apelacyjnego oraz 12 przysięgłych, orzekającego w najcięższych przestępstwach. Kandydaci do funkcji przysięgłego mieli umieć pisać i czytać, posiadać określony majątek lub dochód, ewentualnie wykonywać jeden ze wskazanych zawodów (np. nauczyciela zakładu naukowego, fabrykanta czy rzemieślnika zatrudniającego co najmniej 10 czeladników); ale sprawy wyznania czy pochodzenia społecznego nie odgrywały roli. Wyłanianie przysięgłych odbywać się miało kilkuetapowo: najpierw przy udziale władz powiatu miały być sporządzane ogólne listy wszystkich uprawnionych; potem na zjeździe sędziów pokoju sędziowie ci mieli wybierać z listy ogólnej 120-200 osób, tworzących listę roczną, a z tej dopiero w drodze losowania miał się konstytuować komplet orzekający. Przysięgli mieli orzekać o winie większością głosów. Projekt przewidywał możliwość uchylenia uchwały przysięgłych na korzyść oskarżonego i odesłania sprawy do ponownego rozpoznania przez ławę przysięgłych w innym składzie. Trybunał sędziów zawodowych wyrokować miał w sprawie kary, nie mogąc jednak jej wymierzyć ponad to, czego żądał prokurator.

Projekt Holewińskiego nie został, tak jak i wcześniejsze projekty, wprowadzony $\mathrm{w}$ życie. Tym razem na przeszkodzie stanął wybuch powstania styczniowego, a wraz z jego stłumieniem, carskie represje w stosunku do ludności Królestwa Polskiego. Dopiero w 1876 r. rosyjska reforma sądowa została rozciągnięta na ten obszar, ale sądu przysięgłych nie przyniosła ${ }^{20}$.

Poza krótkim epizodem związanym z działalnością polskich sądów przysięgłych w okresie powstania listopadowego aż do odzyskania niepodległości instytucja ta, jeśli istniała na ziemiach polskich, to tylko za sprawą ustawodawcy zaborczego.

III. Sądy przysięgłych w zaborze pruskim. W krajach niemieckich dyskusja nad instytucją sądów przysięgłych, zapoczątkowana w połowie wieku XIX, głównie pod wpływem wydarzeń rewolucyjnych z 1848 r., stanowiła część szerszej debaty nad udziałem przedstawicieli społeczeństwa w wymiarze sprawiedliwości. Pod wpływem nastrojów politycznych, będących odzwierciedleniem wydarzeń Wiosny Ludów, rosnącą akceptacją zaczął cieszyć się pogląd o istotnej roli sędziów przysięgłych jako reprezentantów uciśnionego ludu. Niemieccy liberałowie uważali ich za ważną gwarancję obywatelskiej wolności. Wyrażano pogląd, że najbardziej są potrzebni w procesach politycznych. Więcej zwolenników miał model francuski niż angielski i to on był preferowany w znanym „Leksykonie państwowym” (Staatslexicon) wydawanym przez Carla von Rottecka i Carla von Welckera. Zgromadzenie Narodowe obradujące we Frankfurcie od czerwca 1848 r. (Parlament Frank-

${ }^{20}$ W. Daszkiewicz, Próby reform procesu karnego..., s. 244-250. 
furcki) włączyło sądy przysięgłych do Katalogu Praw Podstawowych (Grundrechtskatalog), a w następnych latach zostały one wprowadzone w licznych krajach niemieckich. Wzorowano się na doświadczeniach francuskich ${ }^{21}$.

W Prusach instytucję sądów przysięgłych przyniósł ten sam, co w całych Niemczech polityczny prąd, a ponieważ Wielkie Księstwo Poznańskie nie wykazywało już wówczas w zakresie ustroju sądowego odrębności prawnych, instytucja sądu przysięgłych pojawiła się równocześnie i na tym obszarze. Był to pierwszy obszar dawnych ziem polskich, nie licząc epizodu powstańczego, w którym zaprowadzono tę instytucję.

Podstawę do zmian w Prusach dała oktrojowana w 1848 r. przez króla pruskiego Fryderyka Wilhelma IV, choć bardzo niechętnie, konstytucja. Obok absolutystycznych rozwiązań, przyniosła ona bowiem rozwiązania liberalne, stanowiące odzwierciedlenie haseł rewolucyjnych. Wprowadziła Prusy na drogę praworządności i otwarła drogę do reformy organizacji sądów, oznaczającą odrzucenie pozostałości feudalnych i ostateczne ugruntowanie zasady powszechności sądów oraz reformy prawa karnego. Królewskie rozporządzenie z 1849 r. unormowało nowy ustrój sądowy, nie zmieniany już później aż do chwili wejścia w życie nowej organizacji sądownictwa wydanej dla całej Rzeszy Niemieckiej w 1877 r. $^{22}$ Reforma procedury karnej przeprowadzona została również w 1849 r., a rok 1851 przyniósł nowy kodeks karny. Już nawet rewizja konstytucji z 1850 r., przynosząca ograniczenie liberalnych zasad $\mathrm{w}$ wielu sferach, nie wpłynęła na kierunek zmian, jakie zapoczątkowane zostały w wymiarze sprawiedliwości. W 1849 roku powołane zostały do życia sądy przysięgłych. Działały przy sądach powiatowych w składzie 12 przysięgłych i 5 sędziów zawodowych: przysięgli orzekali o winie, sędziowie zawodowi o karze. Właściwość rzeczowa sądów przysięgłych rozciągała się na najcięższe przestępstwa zagrożone karą śmierci lub więzienia powyżej 5 lat i przestępstwa polityczne. Kodeks karny z 1851 r. uściślił tę właściwość. Wzorem francuskim, przeprowadzono podział przestępstw na: zbrodnie, występki i wykroczenia $\mathrm{i}$ to $\mathrm{z}$ uwagi na rodzaj przestępstwa oznaczono odtąd kompetencję sądu przysięgłych. Ustawą wprowadzającą kodeks karny oddano sądom przysięgłym wszystkie przestępstwa uznane za zbrodnie, tj. zagrożone karą śmierci, karą domu poprawy lub więzienia powyżej 5 lat ${ }^{23}$. W innych państwach niemieckich kompetencje sądu przysięgłych oznaczano, albo - tak jak w Prusach - na podstawie rodzaju popełnionego przestępstwa, albo według grożących kar (np. przestępstwa zagrożone karą śmierci lub ciężkiego więzienia) ${ }^{24}$.

${ }^{21}$ K. Kroeschell, Deutsche Rechtsgeschichte Band. 3 (seit 1650), Opladen 1989, s. 163 i n.

${ }^{22}$ Ustawa o ustroju sądownictwa $z$ dnia 27 stycznia 1877 r. (Dziennik Ustaw Rzeszy Niemieckiej 1877, Nr 4, s. 41-80).

${ }^{23}$ Kodeks karny dla państw Królestwa Pruskiego, wraz z ustawa względem zaprowadzenia takowego z dn. 14 kwietnia 1851, Berlin 1851.

${ }^{24}$ S. Glaser, Kompetencja sądów przysięgłych, Lublin 1923, s. 26-27. 
Z czasem zaczęły się ujawniać słabości wprowadzonej instytucji. Zwracano uwagę na jej niedostateczne ugruntowanie w europejskiej, a zwłaszcza niemieckiej tradycji prawnej. Nie atakowano jednak samej idei reprezentacji, lecz co najwyżej jej formę. Wskazywano na konieczność traktowania jej z ostrożnością, a nawet nieufnością, przedstawiano pułapki, jakie mogło pociągać za sobą jej - być może - zbyt pochopne wprowadzenie ${ }^{25}$. Dyskusję nad sądami przysięgłych chętnie podejmowano w trakcie odbywających się w Niemczech zjazdów prawników, gdzie coraz widoczniej ujawniały się różnice poglądów, w końcu powstały dwa biegunowo odmienne obozy: zagorzałych obrońców instytucji (m.in. Wahlberg, Bar, Mayer) oraz jej zapalonych przeciwników (Schwarze, Zachariae, Binder) ${ }^{26}$.

Wejście w życie ustawy o ustroju sądownictwa z dnia 27 stycznia 1877 r., poprzedzone dramatyczną debatą w Reichstagu, w trakcie której stanowisko południowych krajów niemieckich, zwłaszcza Bawarii, przesądziło o jej przyjęciu, oznaczało utrzymanie sądów przysięgłych i to w jednolitej odtąd, dla całej Rzeszy Niemieckiej, formie ${ }^{27}$. W § 80 ustawy w sposób negatywny określono kompetencję sądów przysięgłych, stwierdzając, że do ich właściwości należą zbrodnie niezastrzeżone izbom karnym (działającym w sądach krajowych - Landgerichte) lub Trybunałowi Rzeszy. W ten sposób ustawodawca przekazał sądom przysięgłych rozstrzyganie w następujących zbrodniach: zdrada stanu, zdrada kraju, zbrodnie przeciwko obyczajności, morderstwo, zabójstwo, rozmyślne podpalenie.

Sądy przysięgłych zbierały się w sądach krajowych i składały z 3 sędziów zawodowych i 12 przysięgłych ${ }^{28}$. Urząd przysięgłego był urzędem honorowym i mógł być sprawowany wyłącznie przez Niemców ${ }^{29}$. Polacy w świetle niemieckich regulacji prawnych nie byli dopuszczeni do jego pełnienia, tak więc w tym zaborze, pomimo istnienia sądów przysięgłych i to najwcześniej na ziemiach polskich, nie wykształciła się żadna polska tradycja z nimi związana. Polacy zresztą nie tylko nie mogli być przysięgłymi, ale nie byli też dopuszczani do stanowisk sędziów zawodowych. Powoływanie przysięgłych odbywało się etapami. Najpierw miejscowe władze administracyjne sporządzały tzw. listę pierwotną (Urliste), wspólną dla przysięgłych i ławników ${ }^{30}$. Takie same były też wymagania do pełnienia obydwu funkcji, które ustawodawca niemiecki wskazał - podobnie jak właściwość rzeczową sądu przysięgłych - w sposób negatywny. Niezdolnymi do sprawowania funkcji przysięgłego

${ }^{25}$ P. Stebelski, Sady przysięgłych i sądy tawnicze..., s. 7.

${ }^{26}$ Ibidem, s. 6.

27 Zob. E.R. Huber, Deutsche Verfassungsgeschichte seit 1789, Bismarck und das Reich, Bd. III, Stuttgart 1988, s. 978.

${ }^{28} \S 81$ ustawy o ustroju sądownictwa z $1877 \mathrm{r}$.

${ }^{29}$ Ibidem, $\S 84$.

${ }^{30}$ Ibidem, $§ 85$. 
(i ławnika) były więc osoby, które nie ukończyły 30 lat, nie miały stałego miejsca zamieszkania w okręgu danego sądu krajowego, pobierały wsparcie dla ubogich ze środków publicznych, z powodu ułomności fizycznych bądź umysłowych nie nadawały się do pełnienia funkcji, utraciły wskutek wyroku sądu zdolność do piastowania urzędów i funkcji publicznych ${ }^{31}$. Z listy pierwotnej władze sądowe sporządzały węższą listę osób proponowanych (Vorschlagsliste) do pełnienia funkcji przysięgłych w danym roku. Z tej ostatniej listy sporządzano listę roczną (Jahresliste), na której figurowały nazwiska przysięgłych głównych i pomocniczych. Dopiero z listy rocznej w drodze losowania powoływano 36 przysięgłych, których wpisywano na listę orzekającą, służbową (Spruchliste) ${ }^{32}$.

Postępowanie przed sądem przysięgłych zostało uregulowane w ustawie postępowania karnego z dnia 1 lutego $1877 \mathrm{r}^{33}$ Rozpoczynało je utworzenie ławy przysięgłych. Z listy orzekającej skreślano osoby niezdolne z różnych powodów do pełnienia $\mathrm{w}$ danej sprawie funkcji przysięgłego (rozstrzygnięcie o usunięciu przysięgłego wydawał sąd), a z pozostałych - w liczbie co najmniej 24 - losowano 12-osobowy skład, w taki sposób, że odnośnie do każdego wylosowanego nazwiska najpierw prokurator, a potem oskarżony musieli oświadczyć, czy przysięgłego przyjmują czy też nie. Po utworzeniu ławy przysięgłych następowało zaprzysiężenie przysięgłych lub - jeśli wyznanie nie pozwalało na składanie przysiąg - uroczyste zaręczenie ${ }^{34}$. Po przeprowadzeniu rozprawy przewodniczący sądu wręczał przysięgłym ułożone przez siebie pytania: główne (dotyczyły winy i rozpoczynały się od słów „Czy oskarżony jest winien zarzucanego mu czynu”), pomocnicze (układane wówczas, gdy na rozprawie wyszły na jaw okoliczności, które pozwalały na dokonanie odmiennej niż w akcie oskarżenia kwalifikacji czynu) i uboczne (dotyczyły okoliczności zmniejszających albo zwiększających karalność danego czynu). Pytania musiały być tak sformułowane, by przysięgli mogli na nie odpowiedzieć słowami: „tak” lub „nie”. Przed wyjściem przysięgłych na naradę, przewodniczący sądu udzielał im pouczenia prawnego w takim zakresie, jaki przy rozstrzyganiu danej sprawy był konieczny ${ }^{35}$. Przed rozpoczęciem narady przysięgli wybierali spośród swojego grona zwierzchnika, który następnie kierował obradami i głosowaniem. W trakcie narady przysięgli nie mogli bez zezwolenia opuszczać sali narad ani kontaktować się z nikim z zewnątrz, w razie konieczności mogli wrócić na salę posiedzeń, by uzyskać od przewodniczącego sądu dodatkowe pouczenie. Głosowano większością, przy czym przy każ-

${ }^{31}$ Ibidem, § 32-35.

${ }^{32}$ Ibidem, § 85-92.

${ }^{33}$ Ustawa postępowania karnego z dnia 1 lutego 1877 r. (Dziennik Ustaw Rzeszy Niemieckiej 1877 , s. 346 i n.).

${ }^{34} \S 278-289$ ustawy postępowania karnego z 1877 r.

${ }^{35}$ Ibidem, § 290-300. 
dym rozstrzygnięciu niekorzystnym dla oskarżonego należało zaznaczyć, że wydano je więcej niż 7 głosami, w innych przypadkach stosunku głosów nie podawano. Po zakończeniu narady i powrocie na salę posiedzeń, zwierzchnik odczytywał werdykt w ten sposób, że czytał zadane pytania i złożone na nie odpowiedzi ${ }^{36}$. Jeżeli przysięgli uznali, że oskarżony był niewinny, sąd zwalniał go od dalszego postępowania, w przeciwnym razie - przed wydaniem orzeczenia o karze, wysłuchiwał jeszcze wywodów i wniosków prokuratora i oskarżonego ${ }^{37}$. Przepisy niemieckie dopuszczały możliwość zawieszenia werdyktu przysięgłych. Jeżeli sąd jednomyślnie uznał, że przysięgli pomylili się w głównym przedmiocie sprawy na niekorzyść oskarżonego, uchwałą i to bez uzasadniania swojego zdania mogli przekazać sprawę do ponownego rozpatrzenia w następnej kadencji sądu przysięgłych. W ponownej rozprawie nie wolno już było brać udziału żadnemu z przysięgłych współdziałających przy wydaniu orzeczenia. Na podstawie nowego werdyktu wydanie wyroku było już konieczne ${ }^{38}$. Od wyroków sądów przysięgłych przysługiwała rewizja do Sądu Rzeszy w Lipsku.

Po odzyskaniu przez Polskę niepodległości, na mocy rozporządzenia Ministra b. Dzielnicy Pruskiej z dnia 15 grudnia 1919 r. o organizacji sądownictwa karnego w b. dzielnicy pruskiej, działalność sądów przysięgłych została zawieszona ${ }^{39}$. W praktyce sądy te nie zostały tutaj nigdy reaktywowane, zwłaszcza że nie domagano się ich przywrócenia, bo dla ludności polskiej - niemogącej pełnić funkcji przysięgłego pod rządami pruskiego zaborcy była to instytucja obca, zaś czynnik społeczny był reprezentowany w tamtejszych sądach w postaci ławników. Po przyłączeniu Górnego Śląska do Polski i zaprowadzenia tam polskiego sądownictwa, instytucja sądów przysięgłych (obowiązująca na mocy ustaw niemieckich) została również zawieszona ${ }^{40}$. Tutaj też nie doszło do odrodzenia sądów przysięgłych.

IV. Sądy przysięgłych w zaborze austriackim. Instytucja sądów przysięgłych została wprowadzona na obszarze Austrii po raz pierwszy na mocy procedury karnej z dnia 17 stycznia 1850 r. (Die österreichische Strafprozessordnung $)^{41}$. Wydana na mocy konstytucji z 1849 r. procedura ta, podobnie zresztą jak sama konstytucja, odzwierciedlała idee Wiosny Ludów, które w procedurze karnej wyrażały się realizacją takich postulatów, jak: jawność

\footnotetext{
${ }^{36}$ Ibidem, § 301-308.

${ }^{37}$ Ibidem, $\S 314$.

${ }^{38}$ Ibidem, § 317.

${ }^{39}$ Rozporządzenie Ministra B. Dzielnicy Pruskiej z dnia 15 grudnia 1919 r. o organizacji sadownictwa karnego w b. dzielnicy pruskiej (Tygodnik Urzędowy z dnia 24.12.1919, Nr 185, s. 414).

${ }^{40}$ Rozporzadzenie Ministra Sprawiedliwości z 16 czerwca 1922 r. (Dz. U. 1922, Nr 46, poz. 46).

${ }^{41}$ Die österreichische Strafprozessordnung vom 17 Jänner 1850 erläutert und in Vergleichung mit den Gesetzgebungen des Auslandes dargestellt von Dr. Joseph v. Würth, Wien 1850.
} 
i ustność postępowania, skargowość postępowania, a także przekazanie przedstawicielom społeczeństwa - w formie sądów przysięgłych - orzecznictwa w najcięższych przestępstwach. Austriacka procedura karna wzorowała się na kodyfikacji francuskiej z 1808 r. Nie weszła jednak w życie na terenie ziem polskich, a w samej Austrii także rychło, bo już w 1853 r., wraz z klęską rewolucji i jej haseł, została zastąpiona nowym prawem, które tym razem zostało w Galicji wprowadzone. Sądy przysięgłych zostały zniesione z przyczyn politycznych nawet jeszcze szybciej, bo już na mocy postanowienia z dnia 31 grudnia $1851 \mathrm{r}^{42}$ Pomimo krótkiego ich działania doczekały się wówczas pozytywnych opinii. Pisano o nich tak:

„Każdy kto śledził funkcjonowanie sądów przysięgłych w Austrii, musi przyznać, że generalnie sprawowali oni swój urząd z powagą, roztropnością i w poczuciu własnej godności, bez jakichkolwiek preponderancji (dawn. prymat, przewaga, supremacja - przyp. M.M.P.), orzekali bezpartyjnie i nie wydawali więcej niesprawiedliwych wyroków, niż mogło się ich przytrafiać sędziom zawodowym"433.

Istnienie, choć takie krótkie, sądów przysięgłych przyczyniło się jednak do zebrania pierwszych opinii o instytucji, obcej dotąd ustawodawstwu austriackiemu. „Doświadczenia, które porobiliśmy w krótkim okresie obowiązywania sądów przysięgłych, były pod każdym względem obiecujące"44.

Ustawa zasadnicza o władzy sędziowskiej z dnia 21 grudnia 1867 r. formalnie przywróciła instytucję sądów przysięgłych, przekazując im orzecznictwo w sprawach najcięższych przestępstw, a także przestępstw politycznych i popełnionych treścią pisma drukowanego ${ }^{45}$. Jednak w praktyce dopiero na mocy ustawy z dnia 9 marca 1869 r., i to w okrojonym zakresie, instytucja sądów przysięgłych powróciła do austriackiego procesu. Jej kompetencje, wbrew postanowieniom ustawy zasadniczej, zostały ograniczone wyłącznie do zbrodni i występków popełnionych treścią pisma drukowanego ${ }^{46}$.

Przywrócenie szerszego zakresu działania sądów przysięgłych nastąpiło dopiero na mocy nowej procedury karnej z 1873 r., która weszła w życie

${ }^{42}$ S. Glaser, Kompetencja sądów przysięgłych..., s. 31.

${ }^{43}$ Oryginalny tekst: Weeber, Die Grundprinzipien des Strafprozesses: „,... jedermann, welcher dem Gange der Schwurgerichtsverhandlungen folgte, muss zugestehen, dass im Allgemeinen di Geschworenen in Österreich mit Ernst, Besonnenheit und im Bewusstsein ihrer Würde, ohne jede Präponderanz ihr Amt geübt haben, dass sie unparteiisch nach ihrer Überzeugnung Recht sprechen und dass die Geschworenen nicht mehr ungerechte Urteile gefällt haben, als sie bei rechtskundigen Richtern vorkommen mögen”. Podaję za: S. Glaser, Kompetencja sądów przysięgłych..., s. 31.

${ }^{44}$ Oryginalny tekst: Rechbauer, Materialen, t. 10 „Die Erfahrungen, die wir in der kurzen Zeit, während der wir damals die Schwurgerichte hatten, machten, waren in jeder Beziehung erfreulich". Podaję za: ibidem, s. 31.

${ }^{45}$ Państwowa ustawa zasadnicza z dnia 21 grudnia 1867 r. o władzy sędziowskiej (Austriacki Dziennik Ustaw Państwa 1867, Nr 144).

${ }^{46}$ S. Glaser, Kompetencja sądów przysięglych..., s. 32. 
z dniem 1 stycznia 1874 r. na całym obszarze państwa, w tym na ziemiach polskich ${ }^{47}$. W dużej mierze procedura ta nawiązywała do prawa z $1850 \mathrm{r}$. Orzecznictwu sądów przysięgłych oddano kilka kategorii przestępstw:

1. dokonanych treścią pisma drukowanego (osnową druku);

2. o charakterze politycznym bez względu na wymiar kary;

3. zagrożonych karą co najmniej 5 lat więzienia.

W 1885 r. na mocy tzw. ustawy dynamitowej, właściwości sądów przysięgłych poddano jeszcze 4 rodzaje przestępstw, które były związane z użyciem materiałów wybuchowych i które były zagrożone karą przekraczającą 5 lat więzienia ${ }^{48}$.

Równocześnie z procedurą karną weszła w życie ustawa umożliwiająca czasowe zawieszanie sądów przysięgłych w drodze rozporządzenia wydanego przez ministra sprawiedliwości i potwierdzonego przez radę państwa ${ }^{49}$. Takie zawieszenie było przewidziane dla konkretnie wskazanego okręgu sądowego, na czas oznaczony, maksymalnie do roku, a jego podstawą musiało być stwierdzenie, że pojawiły się „fakty, które wskazują potrzebę tego kroku dla zapewnienia bezstronnego i niezawisłego wymiaru sprawiedliwości" ${ }^{50}$. W miejsce sądu przysięgłych wstępować miał wówczas trybunał I instancji w poszerzonym 6-osobowym składzie.

Sąd przysięgłych składał się z trybunału, który tworzyło 3 sędziów zawodowych i protokolant oraz ławy przysięgłych, w skład której wchodziło 12 przysięgłych. Rolą sędziów przysięgłych było orzekanie co do winy oskarżonego, a sędziów zawodowych - wymierzanie stosownie do winy kary lub orzekanie uwolnienia oskarżonego. Funkcję sędziego przysięgłego mógł sprawować tylko mężczyzna między 30. a 60. rokiem życia, piśmienny, zamieszkujący przynajmniej od roku w danej gminie, posiadający pełnię praw cywilnych i płacący określony minimalny podatek, a niebędący urzędnikiem państwowym, nauczycielem szkoły ludowej, osobą duchowną czy pozostającą w wojskowej służbie czynnej, w służbie pocztowej, kolejowej czy telegraficznej ${ }^{51}$. Naczelnik gminy sporządzał corocznie spośród osób odpowiadających tym kryteriom tzw. listę pierwotną (Urliste), która była podawana do publicznej wiadomości i podlegała weryfikacji dokonywanej przez miejscową ludność. Ostateczna wersja listy pierwotnej, a więc już po dokonanych korektach, była przekazywana staroście powiatowemu, którego zadaniem było jej przedstawienie preze-

${ }^{47}$ Ustawa o postępowaniu karnym wraz z ustawa zaprowadzająca z dnia 23 maja 1873 r. (Austriacki Dziennik Ustaw Państwa 1873, poz. 119).

${ }^{48}$ Ustawa dynamitowa (Austriacki Dziennik Ustaw Państwa 1885, poz. 134).

49 Ustawa z dnia 23 maja 1873 o czasowym zawieszaniu sąów przysięglych (Austriacki Dziennik Ustaw Państwa 1873, Nr 120).

${ }^{50} \S 1$ ustawy z dnia 23 maja 1873 o czasowym zawieszaniu sąów przysięgtych.

51 Tryb powoływania do funkcji sędziego przysięgłego regulowała osobna ustawa $\mathrm{z}$ dnia 23 maja 1873 r. o układaniu list przysięgłych (Austriacki Dziennik Ustaw Państwa 1873, Nr 121). 
sowi (prezydentowi) trybunału I instancji i to ze wskazaniem osób szczególnie nadających się do pełnienia funkcji przysięgłych. Dalsze postępowanie toczyło się w specjalnej komisji, powoływanej przez prezesa trybunału I instancji i miało na celu sporządzenie listy rocznej (Jahresliste) składającej się z listy głównej, na której figurowały osoby najbardziej zdatne do pełnienia funkcji sędziego przysięgłego (Hauptliste) i listy uzupełniającej, składającej się z zastępców (Ergänzungliste). Z listy rocznej losowano następnie listę służbową (Dienstliste), składającą się z 36 przysięgłych głównych i 9 zastępców, która była właściwa dla konkretnej kadencji sądu przysięgłych. Przy czym kadencje zwyczajne rozpoczynały się co trzy miesiące, a kadencje nadzwyczajne - tylko w sytuacjach wyjątkowych ze względu na liczbę lub wagę wniesionych aktów oskarżenia - były zarządzane w dodatkowych terminach ${ }^{52}$.

Dwunastoosobowa ława przysięgłych była wyłaniana dla konkretnej sprawy z listy służbowej, przy udziale stron postępowania, przed rozpoczęciem rozprawy głównej. Przewidziano kilka przyczyn wykluczenia przysięgłych $\mathrm{z}$ udziału $\mathrm{w}$ danej sprawie, m.in. $\mathrm{z}$ uwagi na więzy pokrewieństwa między przysięgłym a oskarżonym, możliwość osiągnięcia jakiejś korzyści przez przysięgłego w razie uniewinnienia lub skazania oskarżonego, udział przysięgłego w danej sprawie już wcześniej w innym charakterze, np. świadka czy rzeczoznawcy ${ }^{53}$.

Po utworzeniu ławy przysięgłych przewodniczący trybunału odbierał od przysięgłych przysięgę, zadając im najpierw pytanie następujące:

„Przysięgacie panowie i ślubujecie Bogu, iż z najsumienniejszą uwagą oceniać będziecie dowody, które przeciw oskarżonemu i za oskarżonym przedstawione będą, iż nie pominiecie bez rozwagi niczego, co by wypaść mogło na niekorzyść oskarżonego, iż się wiernie zastosujecie do ustawy, której macie zapewnić powagę, iż przed orzeczeniem swym nie będziecie się porozumiewać względem tego, co jest przedmiotem rozprawy, z nikim oprócz z współprzysięgłymi, iż nie dacie posłuchu przychylności lub niechęci, bojaźni lub zawiści, lecz owszem z bezstronnością i stałością, jakie znamionują mężów sprawiedliwych i niezawisłych, orzekać będziecie tylko wedle dowodów z oskarżonym i przeciw niemu przywiedzionych tudzież wedle opartego na nich przekonania swego, jak to przed Bogiem i sumieniem swoim odpowiedzieć jesteście gotowi”.

Następnie wzywał każdego przysięgłego z osobna do stwierdzenia: „Przysięgam, tak mi Boże dopomóż ${ }^{54}$. W trakcie rozprawy przysięgłym przysługiwało

${ }^{52} \S 297-298$ procedury karnej.

${ }^{53}$ Ibidem, $\S 306$.

${ }^{54}$ Ibidem, § 313. Warto tutaj wspomnieć, że wyznanie religijne przysięgłego nie czyniło różnicy, przysięga była tak skonstruowana, że osoby różnych wyznań mogły ją bez zastrzeżeń złożyć. Jedynie osoby o światopoglądzie ateistycznym lub niepozwalającym na złożenie przysięgi, zobowiązywali się przez podanie ręki. 
prawo zadawania pytań oraz składanie wniosków dowodowych ${ }^{55}$. Po zamknięciu postępowania dowodowego przewodniczący, po naradzie z trybunałem, układał pytania, które następnie miały być skierowane do ławy przysięgłych. Prawo austriackie przewidywało pytania główne, pytania ewentualne (czyli wypadkowe) oraz pytania dodatkowe. Pytanie główne zmierzało do stwierdzenia, czy oskarżony był winien popełnienia czynu będącego przedmiotem aktu oskarżenia. Jeśli na pytanie główne nastąpiła twierdząca odpowiedź ławy przysięgłych, dalsze pytania nazywano dodatkowymi, a ich celem był rozbiór ustawowych znamion przestępstwa zawartych w pytaniu głównym; mogły one dotyczyć stanu lub okoliczności wykluczających lub uchylających karygodność czynu albo okoliczności obciążających lub łagodzących, prowadzących do zmiany wymiaru lub rodzaju kary. Jeśli na pytanie główne ława przysięgłych odpowiedziała przecząco, wówczas dalsze pytania nazywano ewentualnymi lub wypadkowymi ${ }^{56}$.

Po wręczeniu przez przewodniczącego spisanych pytań, przysięgli udawali się na naradę. Sposób obradowania przysięgłych został szczegółowo uregulowany przez ustawodawcę, który wskazał nie tylko na tryb postępowania w trakcie narady i głosowania, ale również motywy, które powinny przyświecać przysięgłym w trakcie podejmowania decyzji. I tak, zobowiązani byli oni przede wszystkim do staranności i sumienności przy roztrząsaniu środków dowodowych, jakie przedstawiono w postępowaniu, a także do kierowania się swoim sumieniem i przekonaniem $\mathrm{w}$ trakcie głosowania nad przedstawionymi pytaniami. Przysięgli, którzy nie orzekali już w dalszym toku postępowania, a więc odnośnie do skutków prawnych w razie orzeczenia winy oskarżonego, nie powinni $\mathrm{w}$ trakcie narady brać pod uwagę ewentualnych prawnych skutków swojego orzeczenia ${ }^{57}$. Głosowano większością, z tym że pytania co do winy oraz okoliczności obciążających oskarżonego - większością dwóch trzecich głosów; w pozostałych przypadkach - zwykłą większością. W razie równości głosów rozstrzygało zdanie korzystniejsze dla oskarżonego ${ }^{58}$. W zależności od werdyktu ławy przysięgłych, trybunał albo wydawał wyrok uwalniający oskarżonego od zarzutu, albo orzekał odpowiednią karę. Od wyroków sądów przysięgłych służyły dwa środki prawne: zażalenie (w przypadkach zachodzącej nieważności postępowania, np. z uwagi na nienależycie obsadzony sąd przysięgłych) oraz odwołanie. Ten ostatni środek prawny służył jednak tylko przeciw orzeczeniu co do kary (a więc orzeczeniu trybunału zawodowego), nie zaś przeciwko orzeczeniu ławy przysięgłych ${ }^{59}$.

${ }^{55}$ Ibidem, $\S 315$.

${ }^{56}$ Prawa i obowiązki sędziów przysięgłych w Austrii w sposób przystępny wyłożone z dołaczeniem najważniejszych przepisów nowego postępowania karnego tyczących się ławy przysiegglych, zestawił A. U., Lwów, 1874, s. 18.

${ }^{57} \S 326$ procedury karnej.

${ }^{58}$ Ibidem, § 329.

${ }^{59}$ Ibidem, § 343-351. 
Początkowo instytucja sądów przysięgłych budziła w Austrii spory entuzjazm, gdyż uważano ją za jedną z większych zdobyczy osiągniętych w zakresie ustępstw politycznych. Z czasem jednak ustąpił on miejsca refleksjom nad jej kształtem, a nieraz nawet - jej sensem. I tutaj również w końcu rozgorzała dyskusja, w której głosy jej zwolenników przeplatały się z opiniami zdeklarowanych krytyków. Najczęściej powtarzał się zarzut braku właściwego przygotowania laików do pełnienia funkcji sędziów przysięgłych, a zwłaszcza braku choćby elementarnej znajomości przepisów prawa ${ }^{60}$. Zwolennicy instytucji odpierali ten zarzut stwierdzeniem, że do właściwego wykonywania zadań sędziego przysięgłego bardziej niż znajomość prawa potrzebne było jasne zrozumienie obowiązków moralnych, przez które rozumiano: sumienność, spokojny namysł, umiłowanie prawdy i bezstronność. Podkreślano, że przysięgli mieli przecież orzekać według własnego sumienia, nawet bez znajomości obowiązującego prawa. Podnoszono ponadto, że ustawodawca przewidując takie braki w zakresie wiedzy prawniczej, nałożył na przewodniczącego trybunału, a więc zawodowego sędziego, obowiązek udzielania przysięgłym wszelkich niezbędnych pouczeń ${ }^{61}$. Pojawiały się też głosy o zbyt niskim poziomie umysłowym przysięgłych, spowodowanym nazbyt liberalnie określonymi warunkami, jakie powinni spełniać kandydaci. Szczególnie krytykowano orzecznictwo przysięgłych w procesach o przestępstwa popełniane treścią pisma drukowanego. Zarzucano tutaj w szczególności: uleganie zewnętrznym wpływom, kierowanie się głosem opinii publicznej (często błędnej), pogoń za popularnością, stronniczość (mającą czasem podłoże narodowościowe) ${ }^{62}$. Sędziom przysięgłym zarzucano też zbytnią pobłażliwość, która mogła wyrobić społeczne przekonanie o bezkarności niektórych kategorii ciężkich przestępstw, np. dzieciobójstwa. Tę pobłażliwość czasem wprost na rozprawach podkreślali prokuratorzy.

Krytyce podlegała też organizacyjna strona działalności sądów przysięgłych, zwłaszcza sposób wyłaniania ławy, umożliwiający kandydatom uwalnianie się pod różnymi pretekstami od zasiadania w niej. Uważano przy tym, że na skutek uruchomienia sądów przysięgłych zbyt wielu obywateli niepotrzebnie jest odrywanych od ich zwykłych zajęć. Ripostą na to były głosy stwierdzające, że obywatele mają przecież obowiązki wobec państwa i powinność, by je spełniać, ten zaś obowiązek i tak do zbyt uciążliwych nie należy ${ }^{63}$.

Słabości instytucji sądów przysięgłych upatrywano nie tylko w charakterze przysięgłych, ale także w pozycji przewodniczącego składu, a więc sędziego zawodowego. Była to pozycja silna, bo od sędziego zależał ostateczny przebieg postępowania, zwłaszcza sposób przedstawienia dowodów na rozprawie,

\footnotetext{
${ }^{60}$ Prawa i obowiązi sędziów przysięglych w Austrii..., s. 35-36.

${ }^{61}$ Ibidem, s. 36-37.

${ }^{62}$ P. Stebelski, Sady przysięgłych i sady tawnicze..., s. 13.

${ }^{63}$ Prawa i obowiązki sędziów przysięgłych w Austrii..., s. 37.
} 
co nieraz w praktyce decydowało o werdykcie ławy przysięgłych. Spodziewano się więc, że przewodniczący będzie charakteryzował się szczególnymi przymiotami nie tylko intelektu, ale też charakteru. Podkreślano, że do pełnienia tej roli - z uwagi na zróżnicowanie poziomu umysłowego przysięgłych - konieczna jest umiejętność zrozumiałego wyrażania się, znajomość języka i zwyczajów różnych społecznych warstw, umiejętność powściągania emocji podczas rozprawy, opanowanie i umiejętność zapanowania nad uczestnikami postępowania, brak stronniczości oraz umiejętność unikania jakichkolwiek wpływów z zewnątrz ${ }^{64}$. Krytykowano końcowe przemówienie przewodniczącego (resumè). Przemówienie to służyło przypomnieniu przebiegu całej przeprowadzonej rozprawy, ale przede wszystkim zatarciu jednostronnych z natury rzeczy wrażeń po przemówieniach oskarżyciela i obrońcy. Według austriackiego ustawodawcy jedynie przewodniczący trybunału był czynnikiem zdolnym i chętnym do zupełnie obiektywnego i rzeczowego przedstawienia sprawy, opartego nie na własnym przekonaniu, lecz wyłącznie na faktach i ustawie. W praktyce jednak stwierdzano, że przewodniczący przecież również wyrabiający sobie $\mathrm{w}$ trakcie rozprawy określone stanowisko w kwestii winy lub niewinności oskarżonego, w swoim resumè musiał dawać temu pewien wyraz, co mogło stanowić już sugestię dla przysięgłych ${ }^{65}$. Za słabą stronę resumè niektórzy uznawali też tę okoliczność, że przysięgli wiedząc, iż na końcu rozprawy nastąpi jej streszczenie, nie zawsze bacznie uczestniczyli $\mathrm{w}$ całym postępowaniu, a więc $\mathrm{w}$ rzeczywistości nie byli w stanie wyrobić sobie samodzielnej opinii. Drugą część resumè stanowiło udzielenie przysięgłym przez przewodniczącego pouczenia prawnego. Tu głównym zarzutem było to, że pouczenia rzadko przybierały właściwą postać, gdyż niełatwym zadaniem jest przedstawienie laikom w przystępnej formie skomplikowanych nieraz konstrukcji prawnych oraz okoliczność, że przysięgli orzekali o fakcie, a nie jego prawnej kwalifikacji ${ }^{66}$.

W dniu 3 listopada 1892 r. austriacki minister sprawiedliwości wydał reskrypt, w którym przedstawiając wnioski z działalności sądów karnych, zawarł też swoje stanowisko odnośnie do orzecznictwa sądów przysięgłych. Stwierdził pod adresem sędziów przysięgłych:

„,instytucja sądów przysięgłych, żywo atakowana z jednej strony, z drugiej uznawana za niezbędną rękojmię urządzeń liberalnych, niezupełnie odpowiedziała

${ }^{64}$ P. Stebelski, Sądy przysięgłych i sądy tawnicze..., s. 17.

${ }^{65}$ Pamiętnik trzeciego Zjazdu Prawników i Ekonomistów polskich $w$ Poznaniu $w$ dniach 11-13 września 1893 roku, Poznań 1894, s. 79-80.

${ }^{66}$ Zob. dyskusja podczas trzeciego zjazdu prawników i ekonomistów w Poznaniu, w której głos zabrali: dr Mizerski z Poznania, Piotr Stebelski z Lwowa, Zygmunt Dziembowski z Poznania, Józef Rosenblatt z Krakowa, Franciszek Nowodworski z Warszawy, Ferdynand Wilkosz z Krakowa, dr Zins ze Stanisławowa, Pamiętnik trzeciego Zjazdu Prawników i Ekonomistów..., s. 81-84. 
daleko posuniętym oczekiwaniom. Walki życia politycznego nie powinny jej wzruszać, lecz powinna ona pozostać nietkniętą"67.

Słowa te pozostawały w związku ze stosowaną nieraz praktyką polegającą na zwracaniu się przewodniczącego sądu podczas rozprawy do sędziów przysięgłych ze słowami krytyki odnoszącymi się do ich sposobu orzekania. Minister sprawiedliwości domagał się więc powierzania kierownictwa rozpraw $\mathrm{z}$ udziałem przysięgłych tylko sędziom o dużym doświadczeniu zawodowym, potrafiącym zapanować nad skomplikowaną procedurą. Przede wszystkim jednak Ministerstwo Sprawiedliwości opowiadało się za ograniczeniem właściwości rzeczowej sądów przysięgłych, wyłącznie do przestępstw politycznych oraz zbrodni zagrożonych najcięższymi karami oraz zastąpieniem sądów przysięgłych w pozostałych sprawach sądami ławniczymi ${ }^{68}$.

O sądach przysięgłych dyskutowano także podczas zjazdów prawników i ekonomistów polskich organizowanych od lat osiemdziesiątych XIX w. aż do wybuchu I wojny światowej, w których uczestniczyli przedstawiciele ze wszystkich trzech zaborów. Szczególnie podczas drugiego zjazdu, odbywającego się we Lwowie w 1889 r., ujawniły się różnice poglądów. W sprawie wypowiadali się przede wszystkim prawnicy z Galicji, gdyż to zaboru austriackiego dotyczył najszerszy udział Polaków w sądach przysięgłych. Negatywną opinię o instytucji wyraził profesor Uniwersytetu Jagiellońskiego Edmund Krzymuski, uznając ją nie tylko za mało przydatną, ale wręcz szkodliwą dla porządku prawnego. Podkreślał, że niefachowi sędziowie nie mają wystarczającej wiedzy, by móc orzekać o winie. Nieco mniej kategorycznie, ale też krytycznie wyrażał się o sądach przysięgłych profesor Uniwersytetu Lwowskiego Piotr Stebelski, uznając, że w Galicji nie okazały się one użyteczne, co jednak nie przesądza o obiektywnej wartości tej instytucji. Przeciwny pogląd reprezentował profesor Władysław Ostrożyński ze Lwowa, który bronił instytucji. Uczestnicy zjazdu przyjęli ostatecznie wnioski, które można podsumować jako aprobatę dla utrzymania instytucji sądów przysięgłych $\mathrm{z}$ jednoczesnym postulatem poddania jej pewnym modyfikacjom. Miały one dotyczyć podniesienia kwalifikacji kandydatów do funkcji przysięgłych poprzez określenie wyższych wymogów dotyczących wykształcenia i nieskazitelności charakteru oraz wprowadzenia konieczności wynagradzania za sprawowanie tej funkcji $^{69}$. W trakcie trzeciego zjazdu prawników i ekonomistów, który miał miejsce w Poznaniu w 1893 r. (był to jedyny zjazd, który odbył się poza obszarem zaboru austriackiego) na forum sekcji prawniczej podjęto problem reformy sądów przysięgłych. Referaty przygotowali: profesor Władysław Ostrożyński (W jakim kierunku należałoby przeprowadzić reformę sadów przysięgłych, by

\footnotetext{
${ }^{67}$ P. Stebelski, Sądy przysięgłych i sądy tawnicze..., s. 12.

${ }^{68}$ Ibidem, s. 18.

${ }^{69}$ Ibidem, s. 10-11.
} 
instytucję tę uczynić pożyteczniejsza przy wymiarze karnej sprawiedliwości?) $\mathrm{i}$ adwokat z Poznania dr Zins ( $O$ zniesieniu resumè przewodniczacego trybunatu przysięglych $)^{70}$.

Z dłuższej perspektywy ocena sądów przysięgłych, szczególnie w kontekście wszelkich przeobrażeń ustrojowych, którym podlegała monarchia Habsburgów w II połowie XIX w. wypadała raczej korzystnie. Podkreślano, że instytucja ta dawała obywatelom realną możliwość współdziałania z aparatem państwa $\mathrm{w}$ wymiarze sprawiedliwości i z jednej strony była dowodem ustępstw, z drugiej zaś - zaufania strony rządzącej do dojrzałości przedstawicieli społeczeństwa. Sędziowie przysięgli wyłonieni w specjalnej procedurze spośród obywateli mieli przecież ,samoistnie w obronie własnego porządku publicznego, w obronie praw społeczeństwa całego stawać i wyrokować"71.

Po odzyskaniu niepodległości tylko na obszarze dawnego zaboru austriackiego instytucja utrzymała się i to niemal do wybuchu II wojny światowej.

V. Sądy przysięgłych w zaborze rosyjskim. W Rosji sądy przysięgłych zostały po raz pierwszy zaprowadzone wraz z wielką reformą sądową, obejmującą zmianę ustroju sądów oraz postępowanie przed nimi, w 1864 r., a więc najpóźniej spośród państw zaborczych. Wprowadzona wówczas procedura karna z dnia 20 listopada 1864 r. przekazała sądom przysięgłych przestępstwa zagrożone karą połączoną $\mathrm{z}$ utratą lub ograniczeniem praw stanu. $Z$ uwagi na to, że rosyjski kodeks karny (Kodeks Kar Głównych i Poprawczych z 1845 r.) przewidywał, że niemal każda surowsza kara pociąga za sobą pozbawienie lub ograniczenie praw stanu (pod tym ostatnim pojęciem rozumiano utratę przywilejów, np. szlachectwa, orderów, wysługi lat w służbie państwowej, utratę stopni urzędowych lub oficerskich), prawie wszystkie cięższe przestępstwa należały do właściwości sądów przysięgłych. Nowy kodeks karny (Kodeks Tagancewa) z 1903 r. zmniejszał wprawdzie liczbę kar, z którymi wiązało się pozbawienie praw stanu, ale - jak wiadomo - został wprowadzony w życie tylko w części ogólnej, natomiast w części szczegółowej jedynie w odniesieniu do niektórych przestępstw (politycznych i religijnych). Przestępstwa polityczne jednak - inaczej niż w systemie austriackim - bez względu na to, kto je popełnił i jaka groziła za nie kara nie należały do właściwości sądów przysięgłych. Jednak w samej Rosji niektórzy prawnicy byli zdania, że z uwagi na to, iż przy przestępstwach politycznych państwo jest w pewnym sensie „poszkodowanym”, osądzenie takich spraw przez przysięgłych posiadałoby szczególną moralną wymowę ${ }^{72}$.

Przysięgli byli wybierani spośród miejscowej ludności i musieli spełniać określone warunki: posiadać obywatelstwo Cesarstwa Rosyjskiego, płeć mę-

\footnotetext{
${ }^{70}$ Pamiętnik trzeciego Zjazdu Prawników i Ekonomistów...

${ }^{71}$ Prawa i obowiązki sędziów przysięgłych $w$ Austrii.., s. 38.

${ }^{72}$ W. Daniewski, Srawnitielnoje obozrienje niekotorych form narodnawo suda, Moskva 1894.
} 
ską, wiek od 25 do 70 lat, miejsce zamieszkania w danym powiecie co najmniej od dwóch lat, znajomość języka rosyjskiego, niekaralność, pełnienie określonych funkcji czy wykonywanie niektórych zawodów (np. sędziego pokoju honorowego, pracownika poczty i stacji telegraficznej itp.) lub posiadanie gruntów czy majątku ruchomego o określonej wartości, a wreszcie - osiąganie dochodu określonej wysokości ${ }^{73}$. Tak więc z racji pozycji lub statusu majątkowego nie każdy był uprawniony do pełnienia funkcji sędziego przysięgłego. Całkowicie wyłączone były osoby duchowne, wojskowi w służbie czynnej oraz - co ciekawe - nauczyciele szkół ludowych.

Najpierw sporządzano tzw. listy ogólne, osobno dla każdego powiatu; była to kompetencja komisji specjalnie powoływanych raz do roku przez organy powiatowe. Listy ogólne były udostępniane do wglądu miejscowej ludności, a po dokonaniu - w razie potrzeby - stosownych sprostowań przedstawiane gubernatorowi, który również miał prawo do sprostowań. Z list ogólnych wskazane wyżej komisje sporządzały, według własnego uznania, kolejne węższe listy osób, które $\mathrm{w}$ danym roku kalendarzowym miały być wzywane do wzięcia udziału w postępowaniu sądowym. Komisje miały uwzględniać przede wszystkim takie osoby, które ze względu na przymioty umysłowe i moralne najlepiej sprawdzałyby się w roli sędziów przysięgłych. Te kolejne listy liczyły: w Sankt Petersburgu i Moskwie po 1200 osób, w powiatach mających powyżej 100 tysięcy mieszkańców po 400 osób, a w mniejszych powiatach po 200 osób. Obok list kolejnych sporządzano listy zastępców przysięgłych, na które wpisywano tylko osoby mające miejsce zamieszkania w miastach, w których odbywały się posiedzenia sądu okręgowego z udziałem przysięgłych (w Sankt Petersburgu i Moskwie powoływano po 200, a w pozostałych miastach po 60 osób). Do pełnienia obowiązków przysięgłego można było być powołanym tylko raz w roku, a co więcej - osoby które dopełniły tego obowiązków w jednym roku, mogły się wymówić od niego w roku następnym, chyba że w danym powiecie nie było wystarczającej liczby osób uprawnionych do występowania w charakterze przysięgłych.

Trzy tygodnie przed rozpoczęciem sesji sądu przysięgłych odbywało się w siedzibie sądu okręgowego losowanie 30 przysięgłych z listy kolejnej i 6 przysięgłych z listy zapasowej. Losowanie przeprowadzał prezes sądu okręgowego $^{74}$. Spośród tak wylosowanych sędziów, wyznaczano później składy orzekające dla każdej rozprawy odbywającej się w danej sesji sądu

73 Ustawy sądowe obowiąujące w Guberniach Królestwa Polskiego na mocy najwyżej zatwierdzonego 19 lutego 1875 roku postanowienia o zastosowaniu ustaw sądowych z 20 listopada 1864 roku do Warszawskiego Okregu Sąowego, T. I Organizacja sadowa i ustawa notarialna, S. Petersburg 1875, s. 57-69. W tekście zawarte są przepisy, które nie miały wprawdzie zastosowania dla Królestwa Polskiego, ale znajdowały się w oryginalnym tekście rosyjskim z 1864 r. i obowiązywały na obszarze Cesarstwa Rosyjskiego.

${ }^{74}$ Art. 550-551 ustawy postępowania sądowego karnego z 20 listopada 1864. Ustawy sądowe obowiąujące w Guberniach Królestwa Polskiego na mocy najwyżej zatwierdzonego 19 lutego 
przysięgłych. Lista spraw podlegających sądzeniu z udziałem przysięgłych była ogłaszana w miejscowej gazecie gubernialnej, nie później niż dwa tygodnie przed rozpoczęciem sesji ${ }^{75}$.

Zadaniem prezesa sądu okręgowego było zapewnienie prawidłowego przebiegu rozpraw $\mathrm{z}$ udziałem przysięgłych. $\mathrm{Z}$ jednej strony oznaczało to zagwarantowanie samym przysięgłym - niezawodowym przecież sędziom - wszelkiej niezbędnej pomocy poprzez objaśnienie budzących wątpliwość kwestii, z drugiej zaś - podjęcie odpowiednich kroków mających na celu ochronienie przysięgłych przed wpływami z zewnątrz, mogącymi mieć wpływ na ich wyrokowanie. Przepisy prawne umożliwiały nawet w szczególnych przypadkach całkowite odizolowanie przysięgłych od świata zewnętrznego na czas procesu, co w praktyce oznaczało zakwaterowanie ich w budynku sądu ${ }^{76}$.

Wylosowani sędziowie przysięgli mieli obowiązek stawienia się na posiedzenie sądu we wskazanym terminie i tylko bardzo ważne powody powołane w ustawie (np. ważna sprawa służbowa) mogły ich od tego zwolnić. Osoby, które takiej okoliczności nie udokumentowały, mogły być nawet pociągnięte do odpowiedzialności w postaci nałożenia na nie grzywny ${ }^{77}$. Przy ustalaniu składu ławy przysięgłych do konkretnej sprawy, brali udział prokurator lub oskarżyciel prywatny, a także oskarżony i jego obrońca. Przysługiwało im prawo do wyłączenia pewnej liczby przysięgłych (prokuratorowi do 6 , a oskarżonemu do 12 osób) ${ }^{78}$. Przysięgłych dotyczyły też te same właściwie wyłączenia z mocy ustawy od udziału w sprawie, które dotyczyły sędziów zawodowych (np. z uwagi na więzy pokrewieństwa, opieki czy toczący się spór sądowy $)^{79}$. Z liczby niewyłączonych sędziów wyznaczano następnie przez losowanie 12 przysięgłych, którzy wchodzili do konkretnego kompletu orzekającego, oraz 2 sędziów zapasowych ${ }^{80}$. Po ułożeniu kompletu ławy, prezes sądu okręgowego zarządzał odebranie od przysięgłych przysięgi według obrządku wyznania każdego z nich. W razie wyznania niepozwalającego na składanie przysiąg, zastępowało je uroczyste zapewnienie ${ }^{81}$.

Sędziowie przysięgli w trakcie rozprawy zapoznawali się ze wszystkimi dowodami w sprawie, mieli prawo zadawać pytania wszystkim badanym osobom, mogli sporządzać notatki, a w razie potrzeby - zwracać się do przewodniczącego sądu o wyjaśnienie im wszelkich wątpliwości nie tylko prawnej natury ${ }^{82}$. Po

1875 roku postanowienia o zastosowaniu ustaw sądowych z 20 listopada 1864 roku do Warszawskiego Okręgu Sądowego, T. II Ustawa postępowania sq̨dowego karnego, S. Petersburg 1875.

${ }^{75}$ Art. 588 Ustawy postępowania sądowego karnego.

${ }^{76}$ Ibidem, art. 614-616.

${ }^{77}$ Ibidem, art. 648-653.

${ }^{78}$ Ibidem, art. 654-656.

${ }^{79}$ Ibidem, art. 600 .

${ }^{80}$ Ibidem, art. 658-660.

${ }^{81}$ Ibidem, art. 664.

${ }^{82}$ Ibidem, art. 671-677 Ustawy postępowania sqdowego karnego z 20 listopada 1864 r. 
zakończeniu rozprawy przewodniczący sądu wręczał przewodniczącemu przysięgłych listę pytań dotyczących winy lub niewinności oskarżonego ${ }^{83}$. Przysięgli udawali się wówczas na naradę, z której nie wolno było im się oddalać, mogli jednak wrócić na salę rozpraw w celu uzyskania dodatkowych wyjaśnień. Przysięgli głosowali ustnie, oddzielnie na każde pytanie, na końcu głosował ich przewodniczący. W razie równości głosów decydowało to zdanie, które było dla oskarżonego korzystniejsze ${ }^{84}$. Po decyzji przysięgłych, ogłoszonej na sali rozpraw, uznającej oskarżonego za niewinnego, przewodniczący natychmiast ogłaszał oskarżonemu, że jest wolny od odpowiedzialności sądowej i - jeśli był wcześniej zatrzymany - od aresztu ${ }^{85}$. W razie uznania winy przewodniczący sądu wzywał prokuratora do przedstawienia wniosków odnośnie do wysokości kary $^{86}$. Oskarżony i jego obrońca mogli prosić o złagodzenie kary przez prokuratora ${ }^{87}$. Wyroki wydane przez sąd okręgowy przy udziale przysięgłych były ostateczne, co oznaczało, że mogły być uchylane jedynie w drodze kasacji ${ }^{88}$.

Wprowadzeniu na terenie Rosji instytucji sądów przysięgłych towarzyszyły wątpliwości, które wynikały przede wszystkim z braku wcześniejszych doświadczeń $\mathrm{z}$ tą instytucją $\mathrm{w}$ rosyjskim systemie wymiaru sprawiedliwości i konieczności posłużenia się obcymi wzorami: angielskim czy francuską modyfikacją modelu angielskiego ${ }^{89}$. Po latach jej obowiązywania wątpliwości nie rozwiały się, a raczej pogłębiły, prowokując dyskusje. Włodzimierz Spasowicz ${ }^{90}$, profesor Uniwersytetu Petersburskiego i adwokat, pisał:

„wymiar sprawiedliwości bywa nieraz surową, twardą, przykrą koniecznością. Sąd powinien być wedle możności równy, trzeźwo patrzący na następstwa wyroku, nieprzystępny podrażnieniom nerwów, podmuchom aurae popularis, widokom stronnictw; ta tylko nienamiętność i bezkolorowość czyni go zdolnym być regulatorem życia w całym ogromie społeczeństwa, śród walki najsprzeczniejszych interesów, śród zabiegów i ujadania się stronnictw, ona to sprawia, że codzienna walka o byt jednostek i grup w społeczeństwie, hamowana przez sądy, odbywa się prawidłowo w karbach prawem określonej wolności"’11.

Sąd przysięgłych w opinii współczesnych nie zawsze spełniał te warunki, ale jak trzeźwo stwierdzano:

${ }^{83}$ Ibidem, art. 801-828.

${ }^{84}$ Ibidem, art. 806-809.

${ }^{85}$ Ibidem, art. 819.

${ }^{86}$ Ibidem, art. 820.

${ }^{87}$ Ibidem, art. 824.

${ }^{88}$ Ibidem, art. 854-855.

${ }^{89}$ W. Spasowicz, Pisma, T. IV, Petersburg 1892, s. 322.

${ }^{90}$ Zob. biogram Włodzimierza Spasowicza [w:] A. Kijas, Polacy w Rosji od XVII wieku do 1917 roku. Stownik biograficzny, Warszawa-Poznań 2000, s. 328-330.

${ }^{91}$ W. Spasowicz, Pisma..., s. 329. 
„bezwzględna doskonałość jest oczywiście mrzonką; najlepszym sądem będzie zawsze ten tylko, który w porównaniu z innymi, ma więcej zalet przy mniejszych niedostatkach",92.

Za najważniejszą zaletę uznawano zaufanie, jakim w społeczeństwie cieszył się sąd przysięgłych, wyrażające się w poglądzie, że wyroki tego sądu są sprawiedliwe. Zaletą miał być też jego skład mieszany, pozwalający na wielostronne spojrzenie na każdą rozpoznawaną sprawę. Obawiano się jednak zbytniej pobłażliwości przysięgłych, ulegania opinii publicznej, zwłaszcza tej najmniej wyrobionej i narażanie przez to najważniejszych wartości, na straży których stać powinien sąd: życia, zdrowia czy honoru, a które - co podnoszono - w tym sądzie nie zawsze musiały znaleźć właściwą ochronę. Zbyt często, zdaniem sędziów-praktyków, dochodziło pod wpływem współczucia czy po prostu braku rozeznania sędziów-laików, do uniewinniania osób w sposób oczywisty winnych. Zbyt częste były zatem sądowe skandale, podważające autorytet sądu ${ }^{93}$. Postulowano jednak pozostawienie instytucji przysięgłych, przy jednoczesnej konieczności jej zreformowania.

Ustawodawstwo z 1864 r. nie objęło początkowo terenu Królestwa Polskiego, a jedynie tzw. Ziemie Wschodnie. Dopiero 12 lat później, w 1876 r., zdecydowano się rozciągnąc reformę sądową również na obszar Królestwa Polskiego, ale nie bez znaczących różnic w stosunku do pierwotnego tekstu ${ }^{94}$. Przepisy o sądach przysięgłych nie zostały wprowadzone i w procedurze karnej dla Królestwa Polskiego znalazło się wyraźne stwierdzenie, że sprawy dotyczące wszystkich przestępstw będą rozstrzygane bez udziału przysięgłych ${ }^{95}$, a w wydanej w 1914 r. znowelizowanej wersji procedury karnej pominięto już nawet to stwierdzenie. Rezygnacja z sądów przysięgłych w Królestwie Polskim podyktowana była przede wszystkim nieufnością w stosunku do ludności polskiej i niechęcią do dopuszczenia jej do udziału w wymiarze sprawiedliwości. Komisja Prawnicza powołana w 1864 r. do przygotowania reformy sądowej dla Królestwa Polskiego uznała, że instytucja sędziów przysięgłych nie jest potrzebna ludności wiejskiej i mogłaby jedynie stanowić dla niej obciążenie $^{96}$. To stanowisko było $\mathrm{w}$ pełni popierane przez zdecydowaną większość składu Komitetu Urządzającego ${ }^{97}$.

W byłym zaborze rosyjskim sądy przysięgłych funkcjonowały więc jedynie na ziemiach, które nie weszły w obręb Królestwa Polskiego, a powołała je i urządzała rosyjska ustawa postępowania karnego z dnia 20 listopada $1864 \mathrm{r}$.

\footnotetext{
${ }^{92}$ Ibidem.

${ }^{93}$ Ibidem, s. 330-332.

${ }^{94}$ Zob. A. Korobowicz, Sądownictwo Królestwa Polskiego 1876-1915, Lublin 1995, s. 33.

${ }^{95}$ S. Glaser, Kompetencja sadów przysięgtych..., s. 39-40.

${ }^{96}$ A. Korobowicz, Sadownictwo Królestwa Polskiego..., s. 54.

${ }^{97}$ Ibidem, s. 66.
} 
Tutaj jednak, krótko po zakończeniu I wojny światowej, sądy przysięgłych zostały zlikwidowane na mocy rozporządzenia Komisarza Generalnego Ziem Wschodnich z dnia 15 maja 1919 r., w którym wprowadził on wersję rosyjskiej procedury karnej z 1914 r., obowiązującej również na terenie dawnego Królestwa Polskiego. W tej wersji sądów przysięgłych - jak wcześniej była o tym mowa - nie było ${ }^{98}$.

W okresie międzywojennym istnienie instytucji sądów przysięgłych stanęło pod znakiem zapytania. W środowiskach prawniczych zaznaczyły się spolaryzowane poglądy co do sensu istnienia oraz kształtu tej instytucji. Obok zwolenników, podzielonych zresztą w poglądach odnośnie do roli i wewnętrznej budowy sądów przysięgłych, znaleźli się krytycy, a nawet zdecydowani i gorący ich przeciwnicy, gotowi argumentować za zupełnym wycofaniem tej instytucji z systemu prawa. Zwolennikom zabrakło determinacji w walce o stworzenie dla niej właściwego miejsca w systemie wymiaru sprawiedliwości i przekonanie przeciwników oraz sceptyków. Ustawodawca okazał się niezdecydowany i niekonsekwentny, najpierw stwarzając dla tej instytucji ramy konstytucyjne, lecz nie doprowadzając do jej wprowadzenia na obszarze całego państwa, a później - kiedy instytucja ta już właściwie nie działała - nie znosząc jej formalnie w odpowiednim czasie.

THE HISTORY OF JURIES ON POLISH LAND IN THE $19^{\mathrm{TH}}$ CENTURY

\section{Summary}

The institution of the jury has neither long nor rich tradition in the Polish judiciary system. Set up not until the middle of the $19^{\text {th }}$ century by the legislative bodies of the occupying forces, and then - after Poland regained independence - maintained in a limited scope by the Polish legislator, it only functioned for a few decades. However, it was considerably longer noticeable in the sphere of the views and projects formulated mainly by the legal environments. The oldest project of appointing it on Polish land dates back to the days of the Duchy of Warsaw (from 1811), the subsequent one from the constitutional period of the Kingdom of Poland (from 1819) and although there was a lack of acceptance on the part of the legislator and appropriate conditions to execute them, they triggered the first debate concerning the juries on the territory

${ }^{98}$ Rozporzadzenie Komisarza Generalnego Ziem Wschodnich $w$ przedmiocie prawa karnego i postępowania karnego na obszarach wschodnich, podlegajacych Komisarzowi Generalnemu Z. W. (Dziennik Urzędowy Zarządu Cywilnego Ziem Wschodnich 1919, Nr 4, poz. 24). 
of Polish land. Under the rule of the occupying forces these juries appeared almost simultaneously in the Prussian Partition (in 1849) and in the Austrian Partition (in 1850), and a little later - in 1864 - in that part of the Russian Partition which did not form the Kingdom of Poland, which means in the so-called Eastern Borderlands. In the period of the Second Polish Republic the juries existed, but only in the area of the former Austrian Partition. The idea of the jury remained alive also in the post-war Poland when for a short time in the forties there emerged a concept of reintroducing it.

\section{L'HISTOIRE DE LA COUR D'ASSISES SUR LE TERRITOIRE DE LA POLOGNE DU XIXE SIÈCLE}

\section{Résumé}

L'institution des cours d'assises ne jouit pas d'une longue et riche tradition dans le système d'administration de la justice en Pologne. Erigée vers la moitié du XIX ${ }^{\mathrm{e}}$ siècle par les législateurs des occupants, et ensuite - quand la Pologne a retrouvé son indépendance - maintenue par les législateurs polonais, mais sous une forme restreinte, elle a fonctionné uniquement pendant quelques dizaines d'années. Néanmoins, elle a marqué de sa présence les opinions et les projets formulés, avant tout, par le milieu des hommes de loi. Le plus ancien de tous les projets de sa création sur le territoire de la Pologne date de l'époque de Duché de Varsovie (1811), le suivant de la période constitutionnelle du Royaume de Pologne (1819) et malgré le manque d'acceptation pour le législateur et de conditions favorables pour leur réalisation, ces projets ont suscité sur le territoire de la Pologne le premier débat au sujet de cours d'assises. Sous les règnes des envahisseurs les cours d'assises ont apparu à peu près en même temps sous l'occupation prussienne (1849) et autrichienne (1850), et un peu plus tard - en 1864 - dans cette partie des terrains sous l'occupation russe qui n'appartenaient pas au Royaume de Pologne, appelés les Terres de l'Est. A l'époque de la II République les cours d'assises existaient uniquement sur le territoire occupé auparavant par l'Autriche. L'idée des cours d'assise est restée vivante aussi dans la Pologne d'après-guerre, quand, dans des années quarante est née, pour peu de temps, la conception de sa restitution. 